\title{
The Cathar Myth of the Fall: A Late Invention of Independent Heretical Exegesis?
}

\author{
Piotr Czarnecki iD https://orcid.org/0000-0003-4155-4918 \\ Institute for the Study of Religions, Faculty of Philosophy \\ Jagiellonian University \\ piotr.czarnecki@uj.edu.pl
}

\begin{abstract}
Some scholars, following a deconstructivist interpretation of Catharism (which denies the existence of Catharism as dualistic heresy, or at least diminishes the significance of dualism as its distinctive feature) propose a hypothesis which assumes that Cathar dualism was not an idea imported from the East (from the earlier dualist traditions, especially from Bogomilism), but that it emerged independently in the West, later than it is reported by the sources, as an effect of specific scriptural exegesis developed in the dissidents' schools. The main aim of this article is to verify, through the analysis of Biblical exegesis, this hypothesis, on which the myth of the fall - crucial for the dualist doctrine - was built. Based on various sources, both polemical and created by the Cathars themselves, it reconstructs biblical foundations of this crucial myth in two main branches of Catharism: the moderate and the radical (within the latter in two of its options: the angelic doctrine, and the doctrine of the two worlds), comparing them to the analogical exegetical concepts developed earlier by the Bogomils.
\end{abstract}

Keywords: Catharism, medieval heresies, Biblical exegesis

Słowa kluczowe: kataryzm, herezje średniowieczne, egzegeza biblijna

A common feature of contemporary deconstructivist interpretations of Catharism is a denial of the image of Catharism created by traditional historiography. ${ }^{1}$ The level of

\footnotetext{
${ }^{1}$ A radically deconstructivist interpretation was developed in the 1990s by scholars questioning the conclusions of traditional historiography of heresy, under the leadership of Monique Zerner, see: Inventer l'hérésie? Discours polémiques et pouvoirs avant l'Inquisition, M. Zerner (ed.), Nice 1998. Since that time, many scholars have claimed that even the terms "Cathars" and "Catharism" should be abandoned, as they deform our perception of dissidence, see: J.L. Théry, L'hérésie des bons hommes. Comment nommer la dissidence religieuse non vaudoise ni béguine en Languedoc (XIIe-début XIVe siècle)?, "Heresis" 2002, no. 36-37, p. 107. Such a radical approach is nowadays criticized by C. Taylor, and P. Biller,
} 
this denial differs - from total rejection of the existence of Catharism with its dualist octrine and episcopal organization, as in the case of M.G. Pegg, ${ }^{2}$ to the assertion that dualism actually appeared later than in the polemical sources, i.e. in the early thirteenth century, or even in the second half of that century. ${ }^{3}$ What is common, however, for all these interpretations is the denial of any genetic connections of Catharism with the earlier dualist tradition (especially with eastern Bogomilism) and the diminishing of the role of dualism as its distinctive feature. ${ }^{4}$ According to the moderate interpretation promoted by Brenon, Jiménez-Sanchez and Biget, the dualist doctrine appeared as the effect of independent biblical exegesis developed in Western heretical schools, without any external influence. ${ }^{5}$ Unfortunately, such revolutionary statements are not based on an analysis of Cathar exegesis, but rather on the questioning of sources

see C. Taylor, Looking for the 'Good Men' in the Languedoc: An Alternative to 'Cathars', [in:] Cathars in Question, A. Sennis (ed.), York 2016, pp. 242-256; P. Biller, Goodbye to Catharism?, [in:] Cathars in Question, op. cit., pp. 275-277.

${ }^{2}$ M.G. Pegg, The Paradigm of Catharism; or, the Historians' Illusions, [in:] Cathars in Question, op. cit., pp. 21-52; idem, The Corruption of Angels: The Great Inquisition of 1245-1246, Princeton 2001; idem, On Cathars, Albigenses, and Good Men of Languedoc, "Journal of Medieval History" 2001, no. 27, pp. 181-195; idem, Albigenses in the Antipodes: An Australian and the Cathars, "Journal of Religious History" 2011, no. 35, pp. 577-600. A similar approach is presented by J. Théry-Astruc, The Heretical Dissidence of the 'Good Men' in the Albigeois (1276-1329): Localism and Resistance to Roman Clericalisms, [in:] Cathars in Question, op. cit., pp. 79-111. This radical interpretation is criticized by J. Feuchter, J. Arnold and P. Biller, see: J. Feuchter, The 'heretici' of Languedoc: Local Holy Men and Women or Organized Religious Group? New Evidence from Inquisitorial, Notarial and Historiographical Sources, [in:] Cathars in Question, op. cit., pp. 113-130; J. Arnold, The Cathar Middle Ages as a Methodological and Historiographical Problem, [in:] Cathars in Question, op. cit., pp. 56-57, 61-78; P. Biller, Goodbye to Catharism?, op. cit., pp. 282-286.

${ }^{3}$ P. Jiménez-Sanchez, Les catharismes: modèles dissidents du christianisme médiéval, XIIe-XIIIe siècles, Rennes 2008, pp. 207-210, 309-311, 366; R.I. Moore, The War on Heresy: Faith and Power in Medieval Europe, London 2012, pp. 201-219, 255-257; see also: R.I. Moore, Principles at Stake: The Debate of April 2013 in Retrospect, [in:] Cathars in Question, op. cit., pp. 257-273.

${ }^{4}$ R.I. Moore, The Formation of a Persecuting Society. Authority and Deviance in Western Europe, 950-1250, Malden 2007, pp. 11-26, 64-68, 111-116; J.L. Biget, Le Midi hérétique: construction d'une image (vers 1140-1209), "Religions et histoire" 2012, 46, pp. 44-45; idem, Les bons hommes sont-ils les fils des bogomiles? Examen critique d'une idée reçue, "Slavica Occitania" 2003, no. 16, p. 161; P. Jiménez-Sanchez, Le catharisme: une origine orientale à deux tendances?, "Slavica Occitania" 2003, no. 16, p. 225; eadem, Les catharismes..., op. cit., pp. 42-48, 345-354; M. Zerner, Du court moment où on appela les hérétiques des "Bougres» et quelques déductions, "Cahiers de civilisation médiévale" 1989, no. 32, pp. 318-324. Connections of Catharism with the Bogomill East are still defended by many scholars, see, e.g. B. Hamilton, Cathar Links with the Balkans and Byzantium, [in:] Cathars in Question, op. cit., pp. 131-150; P. Biller, op. cit., pp. 288-291; C. Taylor, Evidence for Dualism in Inquisitorial Registers of the 1240s. A Contribution to a Debate, "History" 2013, no. 98, pp. 319-345; T. Drakopoulos, L'unité de Bogomilo-Catharisme d'après quatre textes latins analysés à la lumière des sources byzantines, Geneve 2010, http://archiveouverte.unige.ch/unige:12233 [access: 01.09.2018], pp. 6-39, 252-262.

${ }^{5}$ P. Jiménez-Sanchez, De la participation des cathares rhénans (1163) à la notion d'hérésie générale, "Heresis" 2002, no. 36-37, pp. 204-217; eadem, Variations spatiales et temporelles dans l'organisation et dans l'encadrement des communautés dites "cathares», "Heresis" 2003, no. 39, pp. 38, 58-60; eadem, Les catharismes..., op. cit., pp. 354-376; J.L. Biget, Réflexions sur «l'hérésie» dans le Midi de la France au Moyen Âge, "Heresis" 2001, no. 36-37, pp. 39-44, 46-51; A. Brenon, Le faux problème du dualisme absolu, "Heresis" 1993, no. 21, pp. 61-74; E. Werner, L'evangelie de Jean et le dualisme medieval, "Heresis" 1989, no. 12, pp. 15-24. See also: R. Poupin, La papauté, les Cathares et Thomas d'Aquin, Portet-sur-Garonne 2000, pp. 122, 178-180. 
which confirm Cathar connections with the East. ${ }^{6}$ That is why in this article I am going to focus on the issue of Cathar exegesis, which was the foundation of the myth of the fall - the core of dualist doctrine - to verify if such revolutionary statements are probable in the light of available source materials.

As Catharism was not a doctrinal monolith, this exegesis should be analysed separately in each of its branches. In the case of moderate Catharism, earlier (twelfth century) French and German sources focus mainly on ethics and religious practice. Their authors do not give precise information concerning the doctrine and biblical exegesis, often comparing the heretics to the ancient Manichaeans. ${ }^{7}$ The myth of the fall is already well described by later Italian sources from the end of the twelfth and thirteenth century, such as: Manifestatio heresis catharorum quam fecit Bonacursus (1176), De heresi catharorum in Lombardia (1200-1210), the summa of Peter of Verona (1235), of Jacob de Capellis (1240-1260), Moneta of Cremona (1240), Rainer Sacchoni (1250) and Tractatus de hereticis written probably by the inquisitor Anzelm of Alessandria (1270). ${ }^{8}$ These sources show clearly that all the elements of the myth of the fall, explaining the origins of evil, professed by the moderate Cathars corresponded to those present in the Bogomil apocrypha Interrogatio Iohannis, but what's more important here - a similar situation also occurred with the fragments of the Holy Scriptures on which this myth was built. First of all, moderate Cathars, in exactly the same way as Bogomils, explained the origins of the fall of Satan based on a passage from the Book of Isaiah (Is 14,13-14), showing that originally he had been

${ }^{6}$ P. Biller criticizes the deconstructivist approach, especially that of Pegg and Moore, who form their conclusions based only on selected sources that are favourable to their theory, P. Biller, op. cit., pp. 274 304. Similar accusations were also levelled by M. Roquebert, Le 'déconstructionnisme' et les études cathares, [in:] M. Aurell (ed.), Les Cathares devant l'Histoire. Mélanges offerts à Jean Duvernoy, Cahors 2005, pp. 127-133.

${ }^{7}$ In the case of these early sources, it is usually impossible to determine whether they deal with moderate or radical dualists, see: J. Duvernoy, Le catharisme II. L'histoire des cathares, Toulouse 1979, pp. 107-149.

${ }^{8}$ Vita Haereticorum quam fecit Bonacursus, J.P. Migne (ed.), Patrologia Latina (PL), vol. 204, Parisiis 1855; col. 775-792, more about this source, see: G. Rottenwöhrer, Der Katharismus, vol. 1 (1), Quellen zum Katharismus, Bad Honnef 1982, pp. 48-50; De Heresi Catharorum in Lombardia, A. Dondaine (ed.), "Archivum Fratrum Praedicatorum" 1949, no. 19, pp. 306-312; more about the source, see: A. Dondaine, La hiérachie cathare en Italie I, "Archivum Fratrum Praedicatorum" 1949, no. 19, pp. 298 304; S. Petrus Martyr, Summa contra haereticos, T. Kaepelli (ed.), "Archivum Fratrum Praedicatorum" 1947, no. 17, pp. 320-335; more on this partly-edited source, see: T. Kaepelli, Une Somme contre les hérétiques de S. Pierre Martyr, "Archivum Fratrum Praedicatorum" 1947, no. 17, pp. 295-320; Jacobus de Capellis, Disputationes nonnulae adversus haereticos, D. Bazzocchi (ed.), [in:] L'eresia catara. Appendice, Bologna 1920; see also: W.L. Wakefield, Notes on Some Antiheretical Writings of the Thirteenth Century, "Franciscan Studies" 1967, no. 27, pp. 301-304, 309-315; G. Rottenwöhrer, op. cit., pp. 57-59; Moneta de Cremona, Adversus Catharos et Valdenses libri quinque, T.A. Ricchini (ed.), Roma 1743; see also: G. Rottenwöhrer, op. cit., pp. 59-62; A. Dondaine, Le manuel de l'inquisiteur, "Archivum Fratrum Praedicatorum" 1947, no. 17, pp. 179-180; Summa Fratris Raineri de ordine fratrum praedicatorum, de Catharis et Pauperibus de Lugduno, A. Dondaine (ed.), [in:] A. Dondaine, Un Traité Neo-Manicheen du 13 siècle, le Liber de duobus principiis suivi d'un fragment de Rituel Cathare, Roma 1939, pp. 64-78; see also: F. Šanjek, Raynerius Sacconi O.P. Summa de catharis, "Archivum Fratrum Praedicatorum" 1974, no. 44, pp. 31-41; Tractatus de Hereticis, A. Dondaine (ed.), "Archivum Fratrum Praedicatorum" 1950, no. 20, pp. 308-324; see also: A. Dondaine, La hiérarchie cathare en Italie II, "Archivum Fratrum Praedicatorum" 1950, no. 20, pp. 235-239. 
a good angel, but later rebelled against God, led by pride. ${ }^{9}$ Of course, this analogy cannot constitute proof of the dependence of the Cathar conception on the Bogomil one, because the idea that pride was the sin which caused the fall of Satan is common in Christianity. The situation is similar in the case of the identification of Satan with the apocalyptic dragon ( $\operatorname{Rev} 12,4)$, which is present in moderate Catharism, Bogomilism and Catholicism. ${ }^{10}$ It is, however, much more difficult to find such allembracing analogies in the case of the identification of Satan with the unjust steward from the Gospel of St. Luke (Lk 16,1-8), which was mentioned by Peter of Verona when reporting the myth of the moderate Cathars. ${ }^{11}$ Here the only analogy can be found in the Bogomil Interrogatio Iohannis, where Satan, after he had decided to rebel against God, started to tempt the angels with the words of the unjust steward. ${ }^{12}$ In Interrogatio we can find another characteristic theme, reported by Italian sources - the identification of Satan with the Unmerciful Servant, from the Gospel of St. Mathew (Mt 18,23-35). ${ }^{13}$ According to Interrogatio - Satan, after he had been expelled from heaven, asked God for mercy through the words of the unmerciful servant: "Be patient with me, and I will pay back everything." 14 In the Bogomil sacred book we can also find the sources of the most distinctive element of the Cathar myth of the fall - the identification of human spirits with angels - which is present both in the moderate and the radical version. As we read in this source - Satan, after he had formed the first human bodies, ordered the angel from the second heaven to enter the body of Adam, and the angel from the first heaven to enter the body of Eve. ${ }^{15}$

${ }^{9}$ IR 44: Et cogitavit volens ponere tronum suum super nubes et esse similis altissimo. The fall of Lucifer, caused by pride in the Italian sources, see: PV 325, MC 110.

${ }^{10}$ Interrogatio Iohannis, E. Bozoky (ed.), [in:] eadem, Le livre secret des cathares. Interrogatio Iohannis. Edition critique, traduction commentaire, Paris 2009, p. 52: Precepit pater meus et transfiguravit se propter elationem suam et abstulit lumen glorie sue ei, et facies eius sicut ferrum fuit fervens ab igne et tota species faciei eius fuit sicut hominis, et habuit VII caudas trahentes tertiam partem angelorum dei. For an analogical theme in moderate Catharism, see: S. Petrus Martyr, op. cit., p. 325.

${ }^{11}$ S. Petrus Martyr, op. cit., p. 325: ... alii vero, qui negant duo esse principia [...] simul opponuntur quod deus preposuerit eum aliis angelis in prelatum, sed quia male se habuit in illa prepositura volebat eum eicere deus et ille petit a deo misericordiam, sed eo postea se non corrigente per prelium magnum eiectus est a deo cum omnibus angelis qui eum diligere videbantur.

${ }_{12}$ Interrogatio Iohannis, p. 50: Quantum debe domino tuo? Et primus respondit: C chados olei. Et dixit ei: Accipe cautionem et sede et scribe L. Et alii dicit :Tu vero quantum debes domino tuo? Qui ait: C choros tritici. Et ait illi: Tolle cautionem tuam et sede et scribe cito octuaginta'. Et ascendebat ad alios celos ita dicens adscenditque usque ad quintum celum seducens angelos invisibilis patris.

${ }_{13}$ Tractatus de Hereticis, p. 312: Intelligit autem potencialiter vel quia diabolus habuit potentiam quam habuit naturaliter a prima condicione a Deo, vel quando diabolus secundum eos dixit Deo: "Pacientiam habe in me etc" tunc Deus dedit diabolo potentiam formandi omnia. See also: S. Petrus Martyr, op. cit., p. 325; Moneta de Cremona, op. cit., p. 110.

${ }^{14}$ All the Biblical citations in English are taken from the New Revised Standard Version Catholic Edition (NRSVCE). Interrogatio Iohannis, p. 54: Et descendens de celo Sathanas in firmamentum hic nullam requiem poterat facere neque hii qui cum eo erant. Rogavitque patrem dicens: Peccavi, patientiam habe in me; omnia reddam tibi. Pater misertus est eius et dedit ei requiem facere quod vult usque ad diem septimum.

${ }^{15}$ Interrogatio Iohannis, p. 58: Et cogitavit facere hominem in servitio sibi et tulit limum de terra et fecit hominem similem sibi. Et precepit angelo secundi celi introire in corpus luti et tulit de eo et fecit alium corpus in forma mulieris precepitque angelo primi celi introire in ilium. 
Although this element of the doctrine was crucial for the majority of Cathar groups, it had very weak biblical foundations. ${ }^{16}$ According to the De heresi and Moneta of Cremona, moderate Cathars from Concorezzo quoted the abovementioned parable of the unmerciful servant, identified with Satan. His debtor, whom he had begun to choke, saying "Pay back what you owe me" was the angel, imprisoned in the body of Adam. ${ }^{17}$ Manifestatio of Bonacursus and Moneta also mention that the Cathars related the parable of the Good Samaritan (Lk 10,30) to this specific anthropological conception. In their allegorical interpretation, the man going down from Jerusalem to Jericho was the angel going down from the heavenly Jerusalem; the robbers who attacked him were the demons who deprived him of heavenly glory and imprisoned him in this world, and the good Samaritan was Jesus, who came to save him. ${ }^{18}$ As we can see, these fragments of the Holy Scripture are not especially convincing foundations for the revolutionary idea of the preexistence of spirits in heaven, and it seems more probable that the source for this doctrine was another apocrypha used by the Bogomils - the Vision of Isaiah. ${ }^{19}$

As we can see, all the crucial elements of the myth of the fall professed by the moderate Cathars (and their biblical foundations) were borrowed from the Bogomil Interrogatio Iohannis, which is unsurprising, because we know that this apocrypha was brought to Italy around 1190 by the heretic bishop, Nazarius of Concorezzo, and later was also known in southern France. ${ }^{20} \mathrm{~A}$ similar situation occurred in relation to the Vision of Isaiah. ${ }^{21}$ This complete dependence of the exegesis of moderate Cathars on Bogomil models is a strong argument against the assumption that the Cathar doctrine was the effect of independent exegesis, developed in the heretical schools.

The situation looks a bit different in the case of the radically dualistic doctrine. First of all, within this option we had two sub-doctrines, with significantly different versions of the myth of the fall - the first (and earlier), identifying human spirits with the angels that had fallen from heaven (which can be called angelic) and the second, according to which the spirits preexisted in heaven in the kingdom of the Good God

${ }^{16}$ Only the adherents of the doctrine of the two worlds, described below, did not identify human spirits with the angels.

${ }_{17}$ De Heresi..., op. cit., p. 310: Et dicunt, quod lucifer ille formavit de limo terre formam ade et in illa forma suffocavit illum bonum angelum secundum quod dicitur in evangelio: ,, Tenens suffocabat illum dicens: Redde quod debes"; Moneta de Cremona, op. cit., p. 110; see also: Tractatus de Hereticis, p. 312; S. Petrus Martyr, op. cit., 325.

${ }_{18}$ Moneta de Cremona, op. cit., pp. 110-111; Vita Haereticorum quam fecit Bonacursus, p. 775.

19 Vision of Isaiah presents the journey of the prophet through the seven heavens to the throne of God. It expresses the idea of the preexistence of souls in heaven, mentioning crowns, thrones and robes of the righteous, left in the seventh heaven, which will be regained after their death.

${ }^{20}$ On the issue of the use of this apocrypha among the Cathars, see: E. Bozoky, Le livre secret des cathares. Interrogatio Iohannis. Edition critique, traduction commentaire, Paris 2009; pp. 26-32, 176 197; eadem, "Livre secret" des cathares: un lien entre l'Orient et l'Occident, "Slavica Occitania" 2003, no. 16, pp. 203-205. One copy of this book survived in the archives of the inquisition in Carcassone with the inquisitor's inscription: Hoc est secretum hereticorum de Concorezo portatum de Bulgaria, plenam erroribus et etiam falsis latinis.

${ }^{21}$ According to the sources, the Cathars knew the Vision of Isaiah very well: see: A. Acerbi, La Visione di Isaia nelle vicende dottrinali del catarismo lombardo e provenzale, "Christianesimo nella storia" 1980, no. 1, pp. 75-122. 
(which can be called the doctrine of the two worlds). The angelic version was reported for the first time in 1163 by Eckbert of Schönau in Germany, and later at the end of the twelfth Century in France by the theologian Alan of Lille (1178-1202), and the Waldensian Durand of Huesca (Durandus de Huesca, 1179-1207) in his Liber antiheresis. ${ }^{22}$ Far more detailed accounts of this myth can be found in Italian sources: De heresi, Peter of Verona, Moneta of Cremona, Rainer Sacchoni, Jacob de Capellis and also in the Disputatio inter catholicum et paterinum hereticum $(1240-1250) .{ }^{23}$ The common elements for all these accounts are: the existence of two, eternal and equally powerful gods - a good and an evil one - and the identification of human spirits with the angels that had fallen from heaven. According to the most detailed description of De heresi, Lucifer, the son of the evil god, had entered heaven, led by envy, and there - transformed into the angel of light - became popular among the good angels, and was appointed as a steward of the heavenly hosts. After he had revealed his evil intentions and seduced the angels, he changed his shape and in the form of the apocalyptic dragon fought with Michael the Archangel, but was defeated and eventually cast down from heaven with the angels who followed him. After the expulsion, here on Earth, he had these angels imprisoned in material bodies. ${ }^{24}$

As we can see, all the crucial elements of the Cathar radical myth are exactly the same as in the moderate one, and in the Bogomil myth presented in the Interrogatio Iohannis. In the case of the biblical foundations on which it was built, it is very similar. As we learn from De heresi and Moneta, the radical Cathars quoted Is 14,13 to prove that the reason for Lucifer's ascension to heaven was pride, and cited lines from the Revelation of St. John (Rev 12,4; $\operatorname{Rev} 12,7)$ as the best references to the battle which took place in heaven. ${ }^{25}$ What's more important, however, is that the justification for the conception of Lucifer as a steward of the heavenly hosts was found in the parable of the unjust steward from the Gospel of St. Luke (Lk 16,1-8),

${ }^{22}$ Eckbertus Abbas Schonaugensis, Sermones contra catharos, J.P. Migne (ed.), PL, vol. 195, Parisiis 1855, col. 13-103; for more on this source, see: G. Rottenwöhrer, op. cit., pp. 90-91; Alanus de Insulis, De fide catholica contra Haereticos sui temporis, J.P. Migne (ed.), PL, vol. 210, col. 307-428; see also: C. Vassoli, l contra-haereticos di Alano di Lilla, "Bullettino dell'Istituto storico" 1963, no. 75, pp. 123-172; W.L. Wakefield, op. cit., p. 287; Durandus de Huesca, Liber antiheresis, K.V. Selge (ed.), [in:] idem, Die ersten Waldenser. Mit Edition des Liber Antiheresis des Durandus von Osca, vol. 2, Berlin 1967, pp. 3-248; K.V. Selge, Die ersten Waldenser. Mit Edition des Liber Antiheresis des Durandus von Osca, vol. 2, Berlin 1967, pp. ii, IX, XVIII; Ch. Thouzellier, Le Liber anti-heresis de Durand de Huesca et le Contra hereticos d'Ermengaud de Béziers, "Revue d'histoire ecclésiastique" 1960, no. 55, pp. 130-141; A. Dondaine, Durand de Huesca et la polémique anti-cathare, "Archivum Fratrum Praedicatorum" 1959, no. 29, pp. 228-248.

${ }^{23}$ Eckbertus Abbas Schonaugensis, op. cit., col. 16-17; Alanus de Insulis, op. cit., col. 316, 319; Durandus de Huesca, Liber antiheresis, op. cit., p. 236; see also: De Heresi..., op. cit., p. 309; Disputatio inter catholicum et paterinum hereticum, I. Da Milano (ed.), “Aevum” 1940, no. 14, pp. 130-133, (For more on this source, see: A. Dondaine, Le manuel..., op. cit., p. 177); Summa Fratris Raineri, p. 71; Moneta de Cremona, op. cit., p. 4; Jacobus de Capellis, op. cit., p. VII-X; S. Petrus Martyr, op. cit., p. 325.

${ }^{24}$ De Heresi..., op. cit., p. 309.

${ }_{25}$ Ibidem; Moneta de Cremona, op. cit., pp. 4, 39-40; Durandus de Huesca, Liber antiheresis, op. cit., p. 124; see also: Summa Fratris Raineri, p. 71; S. Petrus Martyr, op. cit., p. 325. 
which is a strong argument for its dependence on Interrogatio Iohannis. ${ }^{26}$ The radical Cathars did not find very many new biblical foundations for their myth of the fall. De heresi mentions only that they related the line from Psalm (Ps 79,1): "God, nations have invaded your land to desecrate your holy Temple, to destroy Jerusalem" to the battle in heaven, and according to Moneta, the line from the Book of Obadiah 1,4 as well: "Though you soar high like the eagle and make your nest among the stars I will bring you down even from there, declares the Lord." 27

The radical Cathars paid much more attention to the biblical foundations of the crucial element of their myth - the identification of human spirits with the angels, thus fulfilling the glaring lack of it in the Interrogatio. Already at the beginning of the thirteenth century, De heresi says that to justify this theme they quoted the words of Christ from the gospel of St. Matthew (Mt 15,24): "I was sent only to the lost sheep of the house of Israel," and (Mt 18,11): "For the Son of Man came to save the lost."28 These fragments, and especially the first one, became the main arguments of the radical Cathars in their disputes with their Catholic opponents, as we can conclude from the testimony of various sources in which they appear. ${ }^{29}$ But these fragments were not the only biblical foundations of this specific doctrine. According to Jacob de Capellis, Cathars also quoted the parable of the Lost Sheep (Mt 18,12-14) and of the Lost Coin (Mt 15,8-10), relating them to the minority of the angels who were seduced by Lucifer, and for whose salvation Jesus came into this world. ${ }^{30}$ Disputatio, as the only source, adds that the Cathars also based their doctrine on a fragment of the Book of Sirah (Sir 18,1): "Qui vivet in aeternum creavit omnia simul," proving that all the spirits were created by God at the same time; it was also indirect proof for the identification of the spirits with the angels, who existed in heaven. ${ }^{31}$ Followers of the angelic doctrine also found biblical foundations for the theme of crowns and thrones of angels, abandoned in heaven, which was also present in the moderate myth and in Interrogatio, but in these latter accounts, the theme was not corroborated by any

${ }^{26}$ De Heresi..., op. cit., p. 309: Et dicunt, quod hic Lucifer ex hoc suo regno ascendit superius in celum, pro eo, quod dicitur in Ysaia propheta: 'Conscendam in celum' etc. Et tunc transfiguravit se in angelum lucis. Angelis vero admirantibus propter formam euis et intercedentibus pro eo ad Dominum, susceptus est in celo, et ibi villicus angelorum effectus est. Unde in Evangelio Luce dicitur: 'Homo quidam erat dives qui habebat villicum'. Et in tali villicatione seduxit angelos. See also: Disputatio..., op. cit., p. 130; Moneta de Cremona, op. cit., pp. 4, 42-43; Jacobus de Capellis, op. cit., p. VII.

27 De Heresi..., op. cit., p. 309; Moneta de Cremona, op. cit., p. 40.

${ }^{28}$ De Heresi..., op. cit., p. 309: Later, it is also mentioned by Jacobus de Capellis, op. cit., p. IX: Dicit Christus in evangelio Mathei: non sum missus nisi ad oves que perierant domus Israel, domus Israel intelligent regnum celeste, oves quae perierunt angelos qui ceciderunt esse credunt.

${ }_{29}$ Durandus de Huesca, Liber antiheresis, op. cit., p. 124; Jacobus de Capellis, op. cit., p. IX; Moneta de Cremona, op. cit., pp. 44-45.

30 Jacobus de Capellis, op. cit., pp. IX-X.

31 Where the English translation does not reflect precisely the Latin original, I use quotations from: Biblia Sacra Vulgata, https://www.biblegateway.com/passage/?search=II\%20Timotheum $+4 \&$ version= VULGATE [access: 10.06.2018]. Disputatio..., op. cit., p. 135; Non ne dicitur in libro vestro Ihesu filii Syrac: Qui vivit in eternum creavit omnia simul. Ergo omnes anime insimul sunt create, ergo non de novo creantur sed spiritus celestes fuerunt. 
biblical passage..$^{32}$ According to De heresi, radical dualists found biblical support for this conception in The Second Epistle of St. Paul to Timothy $(2 \mathrm{Tm} 4,8)$ : "In reliquo reposita est mihi corona justitiae, quam reddet mihi Dominus in illa die, justus judex." ${ }^{33}$

As we can see, based on the testimonies of the sources, radical Cathars, especially those from Italy, during the thirteenth century developed biblical exegesis justifying the most important elements of their myth of the fall. However, the small number of these biblical passages, and the fact that the mythological themes fully correspond with those present in the Interrogatio lead to the conclusion that biblical exegesis was not the foundation of the myth, but rather the myth was the foundation of the exegesis, and its main aim was to confirm the doctrine of the Bogomil sacred book. Nevertheless, the attitude of radical Cathars towards Bogomil models was not totally uncritical, and as we can conclude from the accounts of Peter of Verona and Rainer Sacchoni, at least some of them abandoned the problematic theme of the unjust steward from the Gospel of St. Luke, identified with Satan, and, following strong criticism by the Catholics, they (the Cathars) based their doctrine only on much less controversial fragments taken from St. John's Revelation. ${ }^{34}$ This rejection of the crucial theme of the unjust steward shows that under the influence of Catholic criticism, radical Cathars dared to modify the biblical exegesis on which their myth of the fall was built, thus drifting away from the Bogomil concepts.

In the case of the angelic version, we can talk about the gradual evolution and slow abandoning of the Bogomil models, but in the case of the doctrine of the two worlds we have a real revolution both in the form of the myth and in the biblical exegesis on which it was built. The doctrine of two worlds appeared for the first time in France, at the end of the twelfth century, in the Liber antiheresis of the Waldensian, Durand of Huesca (1179-1207), and later a specific folk version was described by two sources at the beginning of the thirteenth century (ca. 1200-1213): Manifestatio heresis albigensium et lugdunensium and De erroribus manichaeorum, and in the 1220's, it appeared again in the so-called Manichaean Treatise (written by an anonymous Cathar author) and in another manuscript by Durand - The Liber contra manichaeos, in which the Cathar treatise was included. ${ }^{35}$ This doctrine arrived much

32 Interrogatio Iohannis, p. 52: Tunc pater precepit angelis suis: Deponite stolas et tronos et coronas ab omnibus angelis audientes eum. Et tulerunt angeli vestimenta et tronos et coronas omnibus angelis audientes eum.

${ }^{33}$ De Heresi..., op. cit., p. 309; Et dicunt quod adhuc sunt vestes et corone in celo et sedes quas amiserunt, et iterum debent eas accipere. De quo apostolus: De reliquo reposita est...

34 The identification of Satan with the unjust steward was widely criticized by Moneta of Cremona, who argues that the God who made his supreme enemy the steward of his angels is either deprived of omniscience or simply evil, see: Moneta de Cremona, op. cit., p. 43. The new version, based only on the Revelation of St. John, is described by Summa Fratris Raineri, p. 71: ...diabolus cum suis angelis ascendit in coelum et facto ibi proelio cum Michaele archangel et angelis boni dei extraxit inde tertiam partem creaturarrum dei... and S. Petrus Martyr, op. cit., p. 325.

35 More on Liber antiheresis and Durand of Huesca, see: note 22; Manifestatio haeresis albigensium et lugdunensium, A. Cazenave (ed.), [in:] Die Mächte des Guten und Bösen: Vorstellungen im XII. u. XIII. Jahrhundert über ihr Wirken in der Heilsgeschichte, A. Zimmermann (ed.), Berlin 1977, pp. 384-397; De erroribus manicheorum, J.N. Garvin, J.A. Corbett (eds.), [in:] J.N. Garvin, J.A. Corbett, The Summa 
later in Italy, and here it was professed by a schismatic group of Cathars from Desenzano, led by John of Lugio, from the 1230s onwards. It is described in the polemics of Moneta and Rainer Sacchoni and also in the Cathar theological treatise - Liber de duobus principiis. ${ }^{36}$

The myth of the fall in the doctrine of two worlds differs significantly from the angelic version. It does not talk about angels in heaven, but about the people of God, or the people of Israel, living in a perfect world called the Land of the Living. This land was similar to our world in every aspect, because - according to Durand of Huesca - the Cathars believed that Satan created his own material world in its image. The crucial difference between these worlds was the material of which they were formed - the Land of the Living was created from the perfect, incorruptible elements of the good God, which cannot be perceived with the material eye, while the world of Satan was made of imperfect and transient material elements. ${ }^{37}$ In the Land of the Living there was a court of the good God and heavenly Jerusalem, a sun and a moon, and people lived there in a similar way to how we live in our world. ${ }^{38}$ According to the most vivid description of Manifestatio, in the world of the good God there are rivers, castles, animals, and gold and silver; people live there, eat and sleep, and everyone has a wife and some even have mistresses. ${ }^{39}$ What's more important, however, is that all the events described in the Old Testament took place for the first time in the Land of the Living. There, the people of Israel sinned and were expelled by God to Babylon, i.e. to the material world, which was also identified with the only existing

contra haereticos Ascribed to Praepositus of Cremona, Notre-Dame 1958, p. 292; for more on these sources, see: A. Dondaine, Durandus de Huesca..., op. cit., pp. 261-262; A. Cazenave, Bien et mal dans un mythe cathare languedocien, [in:] Die Mächte des Guten und Bösen..., op. cit., pp. 352-354.

${ }^{36}$ On the issue of the schism of John of Lugio, see: Summa Fratris Raineri, p. 71; on his doctrine: ibidem, pp. 72-76. Most of Moneta's polemics are directed against the adherents of the doctrine of two worlds, as we can conclude from his words, see: Moneta de Cremona, op. cit., pp. 44-57, 61-71. Surviving fragments of Liber de duobus principiis present only some aspects of this doctrine, see: Liber de duobus principiis, A. Dondaine (ed.), [in:] idem, Un traité neo-manichéen du XIIIe siècle,lLe Liber de duobus principiis, suivi d'un fragment de rituel cathare, Roma 1939, pp. 99-109, 110-115, 116-131.

${ }^{37}$ Durandus de Huesca, Liber antiheresis, op. cit., p. 160: Si adhuc obiciunt hoc: "Omnia dupplicia sunt, unum contra unum”, - non sic debet intelligi, ut sint et alia quatuor invisibilia elementa, ad quorum similitudinem hec visibilia sunt create. For more on the description of the Land of the Living, see: ibidem: 149, 156; Durandus de Huesca, Liber contra manicheos, Ch. Thouzellier (ed.), [in:] eadem, Une somme anti-cathare: le Liber contra Manicheos de Durand de Huesca, Louvain 1964, pp. 82, 98, 100-103, 107-109, 147-152, 188, 193, 202, 217-218, 225-231, 214, see also: Summa Fratris Raineri, p. 73.

${ }^{38}$ Tractatus manicheorum, Ch. Thouzellier (ed.), [in:] eadem, Un traité cathare inédit du début du XIIIe siècle d'après le Liber contra Manicheos de Durand de Huesca, Louvain 1961, pp. 94-95: In illo [inquiunt] seculo credimus esse celum novum et terram novam, de quibus Dominus populo suo ait in Ysaia [...] Illic est curia Patris sancta et angelica, de qua Danihel ait [...] De operibus vero et creaturis que sunt ibi, Apostolus ait: Quod nec occulis vidit, nec auris audivit, nec in cor hominis ascendit, que preparavit Deus hiis qui diligunt eum. (For more on this source, see: Ch. Thouzellier, Un traité cathare inédit du début du XIIIe siècle d'après le Liber contra Manicheos de Durand de Huesca, Louvain 1961, pp. 2584); Durandus de Huesca, Liber contra manicheos, pp. 148, 158; Summa Fratris Raineri, p. 73.

${ }^{39}$ Manifestatio haeresis..., op. cit., pp. 385, 385: In illam terram, scilicet viventium, credunt esse civitates et castella suburbana, et villas et nemora, prata, viridarios, aquas dulces et salsas, bestias silvestres et domesticas, canes et aves ad venandum, aurum et argentum, et diversi generis vasa et supellectilia. Dicunt etiam quod unusquisque habebit illic uxorem et quandoque amasiam; comedent et bibent, ludent ac dormient... 
hell. ${ }^{40}$ On the issue of the character of this sin of Israel in heaven, the sources are not unanimous. In the Liber antiheresis, Durand of Huesca says that the people of God sinned in heaven, without giving any further details; in the Contra Manichaeos, however, he says that Satan entered heaven with his troops and spread terror in the Land of the Living, forcing the people of God to $\sin .{ }^{41}$ Rainer Sacchoni in his description of the Italian version writes that the sons of God took the daughters of the evil God for wives and from these sinful unions, Giants were born. ${ }^{42}$ Although the fundamental tenets (the preexistence of souls, sin committed in heaven, and the fall to Satan's material world) are the same as in the angelic version, the form of the myth of the fall in the doctrine of the two worlds is completely different, and - what's especially noteworthy - it does not have analogies in any of the known Bogomil sources, so it seems highly probable that the doctrine of the two worlds was a genuine invention of the Cathars, specifically those from southern France.

Not only was the form of the myth revolutionary here, but, more importantly, the biblical exegesis as well. In contrast to the Bogomils, moderate Cathars and adherents of the angelic doctrine - who based their teachings mainly on the New Testament, rejecting the Old Testament as the work of the evil god (with the exception of the Psalms and Prophets) - Cathars who professed the doctrine of the two worlds accepted the whole Old Testament, using excerpts from it to confirm their teachings. Based on an excerpt from the Book of Sirah (Sir 42,25): "Omnia duplicia, unum contra unum" (which was fundamental for the whole doctrine of two worlds), they argued that the Old Testament described both the events that took place in the material world of Satan, and those from the Land of the Living..$^{43}$ In this heavenly world, there were equivalents of the earthly prophets, for example, good Moses and good Abraham. ${ }^{44}$ Fragments of the Old Testament concerning God, interpreted literally, were related to Satan, and in the allegorical interpretation to the good God..$^{45}$ The author of the Manichaean Treatise begins with a declaration of faith in the only God who created everything (omnia), but then he explains that omnia never means the whole being, but either everything good or everything evil. ${ }^{46}$

${ }^{40}$ On the issue of sin in heaven and the fall of the people of God, see: Durandus de Huesca, Liber antiheresis, op. cit., pp. 121, 152, 156, 183, 197; Summa Fratris Raineri, p. 75; Moneta de Cremona, op. cit., pp. 75-76.

${ }^{41}$ Durandus de Huesca, Liber antiheresis, op. cit., pp. 121, 134, 138, 149, 152; idem, Liber contra manicheos, p. 259: Item si princeps mundi, ut Manichei dogmatizant et fermentant suos heresiothas, et Assur et Elam et alii quos propheta Ezechiel testatur dedisse terrorem in terra viventium, ingressi sunt terram illam cum exercitibus suis et inde animas populi Dei captas in hoc seculum abduxerunt. See also: ibidem, pp. 167, 138, 257-259, 283, 286-87, 303-306.

${ }^{42}$ Summa Fratris Raineri, p. 73: ...populous boni dei duxerunt contra praeceptum ipsius ibidem filias alienigenas in uxores, id est filias alieni dei, sive malorum deorum et ex tali coitu inhonesto et prohibito nati sunt gigantes et multi alii diversis temporibus.

${ }_{43}$ Durandus de Huesca, Liber antiheresis, op. cit., pp. 149, 160; idem, Liber contra manicheos, p. 214; Tractatus manicheorum, p. 102.

${ }^{44}$ Durandus de Huesca, Liber antiheresis, op. cit., p. 183.

${ }^{45}$ See: Liber de duobus principiis, pp. 110-117.

${ }^{46}$ Tractatus manicheorum, op. cit., p. 102: Sic itaque probatur, quod omnia quandoque in divinis Scripturis eterna esse dicuntur, quandoque temporalia, et ideo hoc nomen omnia dupliciter accipitur, 
All the crucial elements of the myth of the fall in the doctrine of the two worlds had strong biblical foundations, which were missing in the angelic version. According to the Liber antiheresis and Contra manichaeos by Durand of Huesca, the idea of the two worlds was based on the above mentioned line from the Book of Sirah (Sir 42,25): "All things come in pairs, one opposite the other." ${ }^{77}$ To prove the existence of the Land of the Living, the Cathars quoted various passages from the Old and the New Testament in which it was mentioned, e.g., Ps 27 (26), Ps 142 (141); Rev 21,1.48 Based on a dramatic description from the seventh chapter of the Book of Job (Job 7), they argued that the world we live in is the only existing hell. ${ }^{49}$ The Cathar author of the Manichaean treatise also adds passages from the Book of Isaiah (Is 65,17): "For I am about to create new heavens and a new earth; the former things shall not be remembered or come to mind," and from The Second Epistle of St. Peter (2P 3,13), "[...] we wait for new heavens and a new earth, where righteousness is at home." The author emphasises the fact that the material world in which we live was not created by God, and is not under his Reign. To prove this, he quotes an excerpt from St. James's Epistle (Ja 4,4): "Adulterers! Do you not know that friendship with the world is enmity with God? Therefore whoever wishes to be a friend of the world becomes an enemy of God," and the words of Christ from St. John's Gospel (Jn 18,36): "My kingdom is not from this world"; (Jn 17,16): "They do not belong to the world, just as I do not belong to the world," and many other passages from the New Testament (1Cor 7,31; 1John 2,15-16; Jn 14,30; Jn 17,9; Jn 17,25; Jn 16,33; Jn 15,19)..$^{51}$ Based on The First Epistle of St. Paul to the Corinthians (1Cor 15,50): “[...] flesh and blood cannot inherit the kingdom of God" and many other fragments both from the Old and the New Testament (Dn 7,14; Lk 1,33; Ps 145,13), the author proves that the Kingdom of God is immaterial, eternal and incorruptible, contrasting these fragments with quotations concerning this world, which will eventually pass $\left(2 \mathrm{P} 3,10\right.$; Mt 15,13). ${ }^{52}$ Also, the description of the Land of the Living with heavenly Jerusalem and the source of life was based on fragments taken from St. John's Revelation (Rev 22,1-2; Rev 2,7; Rev 21,1-2), St. Paul's Epistle to the Galatians (Ga 4,26), and the Books of Isaiah (Is 60,20) and Daniel (Dn 7,10). ${ }^{53}$

iuxta illud Sapientie: Omnia duplicia: unum contra unum. The same conception was later developed by the author of Liber de duobus principiis, see: Liber de duobus principiis, op. cit., pp. 110-115.

${ }^{47}$ Durandus de Huesca, Liber antiheresis, op. cit., p. 160; idem, Liber contra manicheos, op. cit., p. 214; see also note 37.

${ }^{48}$ Idem, Liber antiheresis, op. cit., pp. 144, 149, 156, 213.

49 Ibidem, p. 198; see also Moneta de Cremona, op. cit., p. 57.

${ }^{50}$ Tractatus manicheorum, op. cit., pp. 89, 94.

${ }^{51}$ Ibidem, pp. 91-92: Si mundus positus est in maligno et si non est diligendus neque ea, que in eo sunt, ergo non est credendum quod sint propria Christi quia non sunt ex Patre.

52 Ibidem, pp. 92-93, 109-110, (2P 3,10: But the day of the Lord will come like a thief, and then the heavens will pass away with a loud noise, and the elements will be dissolved with fire, and the earth and everything that is done on it will be disclosed. Mt 15,13: Every plant that my heavenly Father has not planted will be uprooted).

${ }_{53}$ Ibidem, pp. 94-95. 
Adherents of the doctrine of the two worlds found many more biblical foundations justifying the preexistence of souls in heaven than their brothers professing the angelic version. According to the Liber antiheresis of Durand of Huesca, and Moneta, they also quoted the words of Jesus from St. Matthew's gospel (Mt 15,24) - I was sent only to the lost sheep of the house of Israel - and the parable of the Lost Sheep (Lk 15,4-7) and the Lost Coin (Lk 15,8-10), showing that they related to the souls that fell down from heaven. ${ }^{54}$ According to Moneta, they argued that Israel, etymologically, means: "The man who sees God," so consequently the people of Israel are the people who saw God in the literal sense, which means that they lived in heaven. ${ }^{55}$ But these were not the only arguments for the preexistence of souls. The Italian Cathars, described by Moneta, were especially active in this field. They developed Biblical exegesis corroborating this doctrine, paying attention to each of its aspects. To justify the tenet that the people of God lived in heaven at the beginning, they quoted meaningful lines from the Gospel of St. John $(\mathrm{Jn} 3,13)$ : "No one has ascended into heaven except the one who descended from heaven," St. Paul's epistles: to the Philippians (Phil 3,20): "But our citizenship is in heaven" ("Nostra autem conversatio in caelis est") and Ephesians (Eph 1,3): "Blessed be the God and Father of our Lord Jesus Christ, who has blessed us in Christ with every spiritual blessing in the heavenly places." ${ }^{56}$ Based on The Epistle to the Galatians (Ga 6,16), which talks about the "Israel of God": "As for those who will follow this rule - peace be upon them, and mercy, and upon the Israel of God," they argued that - just as everything - Israel also has a double meaning: firstly, the Jewish people living in this world, and secondly, spirits created by the good God, who once inhabited the Land of the Living. ${ }^{57}$

According to Moneta, Italian Cathars also found many fragments in the Holy Scripture to prove that the people of God were created before this material world. Crucial for this issue were lines from the Book of Isaiah (Is 3,19): "Facti sumus quasi in principio," and an excerpt from The Epistle to the Ephesians (Eph 1,4): "[...] he chose us in Christ before the foundation of the world." ${ }^{58}$ Other arguments for the innumerable age of the Israel of God were also found in the book of Sirach (Sir 37,25): "The days of a person's life are numbered, but the days of Israel are without number," Jeremiah (Jer 2,32): "Yet my people have forgotten me, days without number," and Isaiah (Is 46,8-9): "Recall it to mind, you transgressors, remember the former things of old" ("Recordamini proris saeculi"). ${ }^{59}$ To prove that all the spirits were created in heaven at one time (and so, consequently, that they are not created daily as the

${ }^{54}$ Moneta de Cremona, op. cit., pp. 44-45, 47. According to Moneta, the Cathars also quoted Lk 19:10: For the Son of Man came to seek out and to save the lost. Durandus de Huesca, Liber antiheresis, op. cit., p. 236.

${ }^{55}$ Moneta de Cremona, op. cit., p. 44: Volunt autem habere hoc, quia Israel interpretatur vir videns Deum; Israelitae ergo dicuntur Deum videntes. Sed ubi Dominum viderunt? Constat quod non hic. Si igitur viderunt eum, viderunt eum in caelo, ergo fuerunt in ipso.

${ }^{56}$ Ibidem, p. 48.

${ }^{57}$ Ibidem, p. 53: Ex hoc enim volunt, quod duplex sit Israel: unus Dei et alter non.

${ }_{58}$ Ibidem, pp. 48, 73.

${ }^{59}$ Ibidem, pp. 71-72, 76, 51. 
Catholics claimed), the Cathars quoted a line from the Book of Sirah (Sir 18,1): "Qui vivit in aeternum, creavit omnia simul." ${ }^{60}$

The adherents of the doctrine of two worlds also significantly researched the biblical foundations for the crucial tenet of the myth of the fall - the sin of the People of God in heaven - which did not have any scriptural corroboration in the angelic version. As we read in Durand's Contra Manichaeos, they quoted a fragment of the book of Lamentations (Lam 2,1): "How the Lord in his anger has humiliated daughter Zion! He has thrown down from heaven to earth the splendor of Israel" ("Proiecit de celo in terram inclitam Israel"). ${ }^{61}$ The Cathars also related fragments of the Old Testament, concerning the abduction of the Israelites to Babylon by Nebuchadnezzar, to the fall of the people of God from heaven, for example, Jer 29,1-2; Jer 39,1-10; and Ez 36,24, identifying Nebuchadnezzar with Satan. ${ }^{62}$ We suspect that such an exegesis of the biblical fragments concerning Babylonian Captivity appeared in the doctrine of the two worlds much earlier, because Durand of Huesca in his Liber antiheresis says that the heretics related the words of Psalm (Ps 137[136],1-4): "How could we sing the Lord's song in a foreign land?" to the spirits fallen from heaven. ${ }^{63}$ According to Moneta, Italian Cathars quoted the same fragment of the Book of Lamentations (Lam 2,1 ) as their French brothers to corroborate the sin of the spirits in heaven, but the rest of the quotations they used show that in biblical exegesis, they did not follow French patterns passively. ${ }^{64}$ They related words from Isaiah to the sin of the spirits in heaven: (Is 24,21-22): "On that day the Lord will punish the host of heaven in heaven, and on earth the kings of the earth. They will be gathered together like prisoners in a pit, they will be shut up in a prison, and after many days they will be punished," arguing, that the prison meant the material world, belonging to Satan. The same prison for souls, who sinned in the world of the good God was mentioned, they believed, in The First Epistle of St. Peter: (1P 3,19-20), which says that Christ "went and made a proclamation to the spirits in prison, who in former times did not obey." 65 It seems, however, that the crucial biblical argument quoted by the Italian Cathars for the sin of Israel in heaven was the parable of the Prodigal Son from the Gospel of St. Luke (Lk 15,11-32). Of course, at first glance, it may seem that the identification of the prodigal son with the spirits who sinned in heaven is rather artificial - just as is the parable relating the unjust steward to Satan - nevertheless, in this case, the Cathars found a strong argument to justify their interpretation in the words said by the prodigal son

${ }^{60}$ Ibidem, p. 69.

${ }^{61}$ Durandus de Huesca, Liber contra manicheos, op. cit., p. 303; see also: Moneta de Cremona, op. cit., p. 51.

${ }^{62}$ Durandus de Huesca, Liber contra manicheos, op. cit., p. 257; see also: Moneta de Cremona, op. cit., p. 42.

63 Durandus de Huesca, Liber antiheresis, op. cit., p. 137: Hac auctoritate se tutantur heretici dicentes se esse de celo translatos in hanc terram, quam dicunt alienam.

${ }^{64}$ Moneta de Cremona, op. cit., p. 51.

${ }^{65}$ Ibidem, pp. 51, 61. 
to his father (Lk 15,21): "Peccavi in coelum et coram te," which in their opinion were ultimate proof of the fact that the sin was committed in heaven. ${ }^{66}$

Although all the adherents of the doctrine of two worlds claimed unanimously that the people of God sinned in heaven, their opinions considering the reason for and nature of this sin varied, as did the fragments of the Holy Scripture on which they were based. As it was mentioned above, the French Cathars seemed to blame Satan and his demons - who invaded heaven and established their Reign of terror there - for this sin. The author of the Manichaean Treatise quotes the parable of Weeds among the Wheat (Mt 13,24-30), explaining that the field on which the sower sows the wheat signifies the world of the good God, and the wheat signifies his people, while the enemy, who comes at night to sow weeds is Satan, who entered this world introducing his servants there. Through this parable, the Cathar author wanted to prove that the world of God was at first inhabited by his people, but later was settled by the devil's hosts. ${ }^{67}$ According to Durand's Contra Manichaeos, this invasion of heaven by Satan was presented as the conquest of the realm of the good God. Based on the Revelation of St. John, they described the battle between the dragon and Michael the Archangel (Rev 12,4), three foul spirits (Rev 16,13), and the great whore drunk with the blood of the martyrs (Rev 19,2), who were introduced to heaven by Satan. ${ }^{68}$ Devastation of the Land of the Living by the forces of Satan and the reign of terror which they introduced there were corroborated by fragments of the Book of Job (Job 28,5-6): "Terra de qua oriebatur panis, in loco suo igni subversa est," and of Ezekiel (Ez 32,22-25): from the chapter: Lament over Pharaoh (here identified with the devil): "Their graves are set in the uttermost parts of the Pit. Its company is all around its grave, all of them killed, fallen by the sword, who spread terror in the land of the living. Elam is there, and all its hordes around its grave; all of them killed, fallen by the sword, who went down uncircumcised into the world below, who spread terror in the land of the living." ${ }^{69}$

A totally different interpretation of the issue of $\sin$ in heaven was proposed by the Cathars from Italy. According to Moneta, Satan's invasion of heaven did not cause the sin of the people of God, but inversely - the sin of the people of God caused punishment in the shape of Satan's invasion, which was permitted by God. This concept was confirmed, according to the Italians, by passages from the book of Jeremiah (Jer 25,8): "Because you have not obeyed my words, I am going to send for all the tribes of the north, says the Lord, even for King Nebuchadnezzar of Babylon, my servant,

${ }^{66}$ Moneta de Cremona, op. cit., p. 46: Per hunc autem filium adolescentiorem intelligent creaturas iam dictas, vel aliquam illarum, quae dicit: peccavi in caelum et coram te. Et ita volunt quod aliquando fuerit in caelo.

${ }^{67}$ Tractatus manicheorum, op. cit., p. 96: Sed falsi expositores hunc agrum mundum presentem asserunt, quem Dominus suum esse dixit: quod nobis falsum esse videtur. In mundo etenim, de quo Dominus loquitur, boni prius fuerunt, postea vero mali.

${ }^{68}$ Durandus de Huesca, Liber contra manicheos, op. cit., p. 154: Et quis esset tam vecors ut sentiret in illo celo esse tres immundos spiritus in modum ranarum et drachonem cum Michaele archangelo preliantem. [...] Item quis esset tam insipiens, mente captus, qui reretur in illo celo esse magnam meretricem que corrumpit terram in prostitucione sua, que dicitur ebria esse de sanguine sanctorum et de sanguine martytum Ihesu?

${ }^{69}$ Ibidem, pp. 257, 259. 
and I will bring them against this land and its inhabitants," St. Paul's Epistle to the Romans (Rom 9,17): "For the scripture says to Pharaoh, «I have raised you up for the very purpose of showing my power in you, so that my name may be proclaimed in all the earth» ${ }^{70}$ and (Rom 11,32): "For God has imprisoned all in disobedience so that he may be merciful to all." 71 Of course, the assertion that good God allowed Satan to act against his people in heaven to show his power cast a shadow on his goodness, and led to the conclusion that he was at least partly responsible for the fall. Of course, Italian Cathars were fully aware of it, especially John of Lugio, schismatic bishop of the church of Desenzano, and probable author (or at least ideological father) of the theological treatise Liber de duobus principiis. ${ }^{72}$ As we can conclude from this writing, and from the description of the inquisitor Rainer Sacchoni, he had introduced an unconventional doctrine explaining all the actions of the good God that can be considered evil. According to John of Lugio, the will of God is unambiguously good; however, he is not able to fulfill it entirely, because it was made impossible by his enemy - the evil principle, who acted in him eternally, inducing him to evil actions against his creatures. Just as God was originally perfectly good, so too were his People; nevertheless, similarly to the Creator they were not able to realize their good will, contained in their good nature, because the evil principle had eternally polluted it with the inclination to evil (malitia). Although this doctrine looks rather artificial and even absurd, it was also corroborated by passages found by John of Lugio in the Holy Scripture, for example in the Book of Job (Job 2,3): "The Lord said to Satan [...] you incited me against him [Job], to destroy him for no reason," and in St. Paul's Epistle to the Romans (Rom 8,20): “[...] for the creation was subjected to futility, not of its own will but by the will of the one who subjected it..."73

As we can see, in the doctrine of the two worlds, all the elements of the myth of the fall had their biblical foundations, and - what's especially noteworthy - these biblical foundations seem to have been found by the Cathars, because they do not have analogies in Bogomilism. Does this mean, however, that this myth emerged as the effect of independent scriptural exegesis, developed by the Cathars without any external influence? When we take a look at French sources describing the doctrine of the two worlds, we can come to the conclusion that the key to the Cathar exegesis was ontological dualism, developed on the basis of a specific interpretation of the prologue of St. John's Gospel (Jn 1,1-3), assuming the existence of two totally separate

${ }^{70}$ Moneta de Cremona, op. cit., p. 42: Sunt ergo verba ista boni Dei ad Diabolum secundum te et ipse dictus est Pharao, sicut credis.

${ }^{71}$ Ibidem, p. 52.

72 A. Dondaine, Un Traité Neo-Manicheen du 13 siècle, le Liber de duobus principiis suivi d'un fragment de Rituel Cathare, Roma 1939, pp. 14-19.

${ }^{73}$ Summa Fratris Raineri, p. 74: ...Ipse Iohannes dicit, videlicet, quod deus non est omnipotens. Dicit tamen quod deus vult et potest omnia bona quantum in ipso est et in suis creaturis quae sibi necessario obtemperant; sed impeditur haec dei voluntas et potential ab hoste suo. Item quod alteruter agit in alterutrum ab eterno, et quod causa mala id est deus malus agit in deum verum et in eius filium atque in cuncta eius opera ab eterno. [...] Unde concludit ex praemissis quod bonus deus non potuit perfectas facere creaturas suas quamvis hoc voluerit, et hoc sibi et creaturis suis accidit propter resistentiam mali dei qui actum suum sive quamdam malitiam ab aeterno inseruit in eas, ex qua malitia creature habuerunt posse peccare. See also: Liber de duobus principiis, op. cit., pp. 88-92. 
beings - a good one, whose essence was caritas, and an evil, material one - created by Satan, whose essence was nihil. This interpretation emerged early, at the end of the twelfth century, when it was mentioned by Alan of Lille and Durand of Huesca in his Liber Antiheresis; later it was developed by the anonymous author of the Manichaean Treatise, but - and this should be underlined - it also did not have direct analogies in the Bogomil sources. ${ }^{74}$ So, at first glance it may seem that we have further evidence for the interpretation according to which the Cathars were evangelical dissidents who created their doctrine based on their own biblical exegesis, without Bogomil influences. Such an option, however, is not so probable when we consider the fact that this original exegesis did not lead the Cathars to any innovative conclusions, because all the crucial elements of the myth of the fall in the doctrine of the two worlds perfectly corresponded to those from the angelic version, moderate Catharism and Bogomil Interrogatio. Just as in the earlier versions, we can find here the preexistence of spirits, their sin in heaven and the fall to the material world, created by Satan. Of course, we cannot deny that the adherents of the doctrine of two worlds managed to create original scriptural exegesis, independent of the Bogomil models, in contrast to their brothers professing an angelic or moderate version, but this exegesis was still a servant of the mythological themes borrowed from the Eastern dualists.

\section{References}

\section{Sources}

Alanus de Insulis, De fide catholica contra Haereticos sui temporis, J.P. Migne (ed.), Patrologia Latina, vol. 210.

De erroribus manicheorum, J.N. Garvin, J.A. Corbett (eds.), [in:] J.N. Garvin, J.A. Corbett, The Summa contra Haereticos Ascribed to Praepositus of Cremona, Notre-Dame 1958, p. 292.

De Heresi Catharorum in Lombardia, A. Dondaine (ed.), "Archivum Fratrum Praedicatorum" 1949, no. 19, pp. 306-312.

Disputatio inter catholicum et paterinum hereticum, I. Da Milano (ed.), “Aevum” 1940, no. 14, pp. $125-140$.

Durandus de Huesca, Liber antiheresis, K.V. Selge (ed.), [in:] K.V. Selge, Die ersten Waldenser. Mit Edition des Liber Antiheresis des Durandus von Osca, vol. 2, Berlin 1967, pp. 3-258.

Durandus de Huesca, Liber contra manicheos, Ch. Thouzellier (ed.), [in:] Ch. Thouzellier, Une somme anti-cathare: le Liber contra Manicheos de Durand de Huesca, Louvain 1964, pp. 66336.

Eckbertus Abbas Schonaugensis, Sermones contra catharos, J.P. Migne (ed.), Patrologia Latina, vol. 195, Parisiis 1855, pp. 13-103.

Interrogatio Iohannis, E. Bozoky (ed.), [in:] eadem, Le livre secret des cathares. Interrogatio Iohannis. Edition critique, traduction commentaire, Paris 2009.

Jacobus de Capellis, Disputationes nonnulae adversus haereticos, D. Bazzocchi (ed.), L'eresia catara. Appendice, Bologna 1920.

Liber de duobus principiis, A. Dondaine (ed.), [in:] idem, Un traité neo-manichéen du XIIIe siècle, Le Liber de duobus principiis, suivi d'un fragment de rituel cathare, Roma 1939, pp. 81-146.

${ }^{74}$ Durandus de Huesca, Liber antiheresis, op. cit., p. 209; Alanus de Insulis, op. cit., col. 312, Tractatus manicheorum, op. cit., pp. 102-103 (chapter De hoc nomine nihil). 
Manifestatio haeresis albigensium et lugdunensium, A. Cazenave (ed.), [in:] A. Zimmermann (ed.), Die Mächte des Guten und Bösen: Vorstellungen im XII. u. XIII. Jahrhundert über ihr Wirken in der Heilsgeschichte, Berlin 1977, pp. 384-387.

Moneta de Cremona, Adversus Catharos et Valdenses libri quinque, T.A. Ricchini (ed.), Roma 1743.

S. Petrus Martyr, Summa contra haereticos, T. Kaepelli (ed.), “Archivum Fratrum Praedicatorum" 1947, no. 17, pp. 320-335.

Summa Fratris Raineri de ordine fratrum praedicatorum, de Catharis et Pauperibus de Lugduno, A. Dondaine (ed.), [in:] A. Dondaine, Un Traité Neo-Manicheen du 13 siècle, le Liber de duobus principiis suivi d'un fragment de Rituel Cathare, Roma 1939, pp. 64-78.

Tractatus de Hereticis, A. Dondaine (ed.), "Archivum Fratrum Praedicatorum" 1950, no. 20, pp. 308-324.

Tractatus manicheorum, Ch. Thouzellier (ed.), [in:] eadem, Un traité cathare inédit du début du XIIIe siècle d'après le Liber contra Manicheos de Durand de Huesca, Louvain 1961, pp. 87-113.

Vita Haereticorum quam fecit Bonacursus, J.P. Migne (ed.), Patrologia Latina, vol. 204, Parisiis 1855, pp. 775-792.

\section{Literature}

Acerbi A., La Visione di Isaia nelle vicende dottrinali del catarismo lombardo e provenzale, "Christianesimo nella storia" 1980 , no. 1, pp. 75-122.

Arnold J., The Cathar Middle Ages as a Methodological and Historiographical Problem, [in:] Cathars in Question, A. Sennis (ed.), York 2016, pp. 53-78.

Biget J.L., Le Midi hérétique: construction d'une image (vers 1140-1209), "Religions et histoire" 2012, no. 46, pp. 40-45.

Biget J.L., Les bons hommes sont-ils les fils des bogomiles? Examen critique d'une idée reçue, "Slavica Occitania" 2003, no. 16, pp. 133-188.

Biget J.L., Réflexions sur «l'hérésie» dans le Midi de la France au Moyen Âge, "Heresis" 2001, no. 36-37, pp. 29-74.

Biller P., Goodbye to Catharism?, [in:] Cathars in Question, A. Sennis (ed.), York 2016, pp. 274 313.

Bozoky E., Le livre secret des cathares. Interrogatio Iohannis. Edition critique, traduction commentaire, Paris 2009.

Bozoky E., "Livre secret" des cathares: un lien entre l'Orient et l'Occident, "Slavica Occitania" 2003, no. 16, pp. 199-206.

Brenon A., Le faux problème du dualisme absolu, "Heresis" 1993, no. 21, pp. 61-74.

Cazenave A., Bien et mal dans un mythe cathare languedocien, [in:] Die Mächte des Guten und Bösen: Vorstellungen im XII. u. XIII. Jahrhundert über ihr Wirken in der Heilsgeschichte, A. Zimmermann (ed.), Berlin 1977, pp. 344-387.

Dondaine A., Durand de Huesca et la polémique anti-cathare, "Archivum Fratrum Praedicatorum" 1959, no. 29, pp. 228-267.

Dondaine A., La hiérachie cathare en Italie I, "Archivum Fratrum Praedicatorum" 1949, no., 19, pp. 280-312.

Dondaine A., La hiérarchie cathare en Italie II, "Archivum Fratrum Praedicatorum" 1950, no. 20, pp. 234-324.

Dondaine A. Le manuel de l'inquisiteur, “Archivum Fratrum Praedicatorum” 1947, no. 17, pp. 85194.

Dondaine A., Un Traité Neo-Manicheen du 13 siècle, le Liber de duobus principiis suivi d'un fragment de Rituel Cathare, Roma 1939. 
Drakopoulos T., L'unité de Bogomilo-Catharisme d'après quatre textes latins analysés à la lumière des sources byzantines, Geneve 2010, http://archive-ouverte.unige.ch/unige:12233 [access: 01.09.2018].

Duvernoy J., Le catharisme II. L'histoire des cathares, Toulouse 1979.

Feuchter J., The 'heretici' of Languedoc: Local Holy Men and Women or Organized Religious Group? New Evidence from Inquisitorial, Notarial and Historiographical Sources, [in:] Cathars in Question, A. Sennis (ed.), York 2016, pp. 112-130.

Hamilton B., Cathar Links with the Balkans and Byzantium, [in:] Cathars in Question, A. Sennis (ed.), York 2016, pp. 131-150.

Inventer l'hérésie? Discours polémiques et pouvoirs avant l'Inquisition, M. Zerner (ed.), Nice 1998.

Jiménez-Sanchez P., De la participation des cathares rhénans (1163) à la notion d'hérésie générale, "Heresis" 2002, no. 36-37, pp. 201-218.

Jiménez-Sanchez P., Le catharisme: une origine orientale à deux tendances?, "Slavica Occitania" 2003, no. 16, pp. 207-228.

Jiménez-Sanchez P., Les catharismes: modèles dissidents du christianisme médiéval, XIIe-XIIIe siècles, Rennes 2008.

Jiménez-Sanchez P., Variations spatiales et temporelles dans l'organisation et dans l'encadrement des communautés dites «cathares», "Heresis" 2003, no. 39, pp. 35-62.

Kaepelli T., Une Somme contre les hérétiques de S. Pierre Martyr, "Archivum Fratrum Praedicatorum" 1947, no. 17, pp. 295-335.

Moore R.I., Principles at Stake: The Debate of April 2013 in Retrospect, [in:] Cathars in Question, A. Sennis (ed.), York 2016, pp. 257-273.

Moore R.I., The Formation of a Persecuting Society: Authority and Deviance in Western Europe, 950-1250, Malden 2007.

Moore R.I., The War on Heresy: Faith and Power in Medieval Europe, London 2012.

Pegg M.G., Albigenses in the Antipodes: An Australian and the Cathars, "Journal of Religious History" 2011, no. 35, pp. 577-600.

Pegg M.G., On Cathars, Albigenses, and Good Men of Languedoc, "Journal of Medieval History" 2001, no. 27, pp. 181-195.

Pegg M.G., The Corruption of Angels: The Great Inquisition of 1245-1246, Princeton 2001.

Pegg M.G., The Paradigm of Catharism; or, the Historians' Illusions, [in:] Cathars in Question, A. Sennis (ed.), York 2016, pp. 21-52.

Poupin R., La papauté, les Cathares et Thomas d'Aquin, Portet-sur-Garonne 2000.

Roquebert M., Le 'déconstructionnisme'et les études cathares, [in:] Les Cathares devant l'Histoire. Mélanges offerts à Jean Duvernoy, M. Aurell (ed.), Cahors 2005, pp. 127-133.

Rottenwöhrer G., Der Katharismus, vol. 1 (1), Quellen zum Katharismus, Bad Honnef 1982.

Šanjek F., Raynerius Sacconi O.P. Summa de catharis, “Archivum Fratrum Praedicatorum” 1974, no. 44 , pp. 31-60.

Selge K.V., Die ersten Waldenser. Mit Edition des Liber Antiheresis des Durandus von Osca, vol. 2, Berlin 1967.

Taylor C., Evidence for Dualism in Inquisitorial Registers of the 1240s: A Contribution to a Debate, "History" 2013, no. 98, pp. 319-345.

Taylor C., Looking for the 'Good Men'in the Languedoc: An Alternative to 'Cathars', [in:] Cathars in Question, A. Sennis (ed.), York 2016, pp. 242-256.

Théry J., L'hérésie des bons hommes. Comment nommer la dissidence religieuse non vaudoise ni béguine en Languedoc (XIIe-début XIVe siècle)?, "Heresis" 2002, no. 36-37, pp. 75-117.

Théry-Astruc J., The Heretical Dissidence of the 'Good Men' in the Albigeois (1276-1329): Localism and Resistance to Roman Clericalisms, [in:] Cathars in question, A. Sennis (ed.), York 2016, pp. 79-111. 
Thouzellier Ch., Le Liber anti-heresis de Durand de Huesca et le Contra hereticos d'Ermengaud de Béziers, "Revue d'histoire ecclésiastique" 1960, no. 55, pp. 130-141.

Vassoli C., Il contra-haereticos di Alano di Lilla, "Bullettino dell'Istituto storico" 1963, no. 75 , pp. 123-172.

Wakefield W.L., Notes on Some Antiheretical Writings of the Thirteenth Century, "Franciscan Studies" 1967 , no. 27, pp. 285-320.

Werner E., L'evangelie de Jean et le dualisme medieval, "Heresis" 1989, no. 12, pp. 13-26.

Zerner M., Du court moment où on appela les hérétiques des "Bougres" et quelques déductions, "Cahiers de civilisation médiévale" 1989, no. 32, pp. 305-324. 